\title{
HUBUNGAN ANTARA KETERSEDIAAN PANGAN DENGAN KERAGAMAN PANGAN RUMAH TANGGA BURUH TANI
}

\author{
Association of Food Availability and Dietary Diversity of Household Farm Labour \\ Dewi Prasetyaningtyas ${ }^{1}$, Triska Susila Nindya ${ }^{2}$ \\ ${ }^{1}$ Program Studi S1 Kesehatan Masyarakat, Fakultas Kesehatan Masyarakat, Universitas Airlangga, Surabaya \\ ${ }^{2}$ Departemen Gizi Kesehatan, Fakultas Kesehatan Masyarakat, Universitas Airlangga, Surabaya \\ Email: dew.prasetya@gmail.com
}

\begin{abstract}
ABSTRAK
Ketersediaan pangan menjadi salah satu determinan keragaman pangan. Penelitian ini dilakukan untuk mengetahui hubungan antara ketersediaan pangan dengan keragaman pangan rumah tangga buruh tani di Kabupaten Bojonegoro. Rancang bangun penelitian ini adalah cross sectional. Populasi dalam penelitian ini adalah seluruh rumah tangga buruh tani di RT.17/RW.02 Kecamatan Dander Kabupaten Bojonegoro. Sebanyak 35 responden dipilih secara acak dengan menggunakan teknik simple random sampling. Pengumpulan data dilakukan dengan wawancara menggunakan kuesioner ketersediaan pangan dan kuesioner Household Dietary Diversity Score (HDDS). Analisis data menggunakan uji Chi-Square. Hasil penelitian menunjukkan bahwa ketersediaan pangan buruh tani $(62,9 \%)$ tergolong kurang dan keragaman pangan rumah tangga buruh tani (45,7\%) tergolong sedang. Penelitian menunjukkan bahwa terdapat hubungan antara ketersediaan pangan dengan keragaman pangan rumah tangga buruh tani dengan $p=0,007$. Penelitian ini menyimpulkan bahwa terdapat hubungan antara ketersediaan pangan dengan keragaman pangan rumah tangga buruh tani. Peningkatan ketersediaan pangan pada rumah tangga buruh tani dapat meningkatkan keragaman pangan.
\end{abstract}

Kata kunci: buruh tani, keragaman pangan, ketersediaan pangan

\begin{abstract}
Food availability is one of food diversity determinants. This study was conducted to examine the relationship of food availability with household food diversity among farm labour in Bojonegoro. This was a cross sectional study. The population of this study were farm labour households at RT.17/RW.02, Dander Subdistrict, Bojonegoro District. Thirtyfive samples were randomly selected using simple random sampling. Interviews were conducted using questionnaire of food availability and Household Dietary Diversity Score (HDDS) questionnaire. Data were analyzed using Chi-Square test. The result showed that food availability of farm labour (62.9\%) was less than normative consumption and food diversity of farm labour (45.7\%) was in moderate category. This study also showed that there was relationship between food availability with food diversity of farm labour ( $p=0.007)$. The study concluded that there was relationship between food availability with food diversity of farm workers. Improvement in food availability can increase food diversity.
\end{abstract}

Keywords: farm worker, food diversity, food availability

\section{PENDAHULUAN}

Peraturan Presiden Nomor 22 Tahun 2009 tentang Kebijakan Percepatan Penganekaragaman Konsumsi Pangan Berbasis Sumber Daya Lokal merupakan acuan bagi Pemerintah dan Pemerintah Daerah dalam melakukan perencanaan, penyelenggaraan, evaluasi dan pengendalian Percepatan Penganekaragaman Konsumsi Pangan (P2KP) Berbasis Sumber Daya Lokal. Kegiatan
P2KP ini dibuat untuk mencapai kondisi konsumsi pangan yang belum sesuai harapan dan belum optimalnya pangan lokal dalam mendukung penganekaragaman konsumsi pangan (Badan Ketahanan Pangan, 2009).

Pemenuhan keragaman konsumsi pangan selain berkaitan dengan status kesehatan dan gizi masyarakat dapat juga dijadikan sebagai gambaran pencapaian target Indikator Millenium 
Development Goals (MDGs). Masih tingginya angka gizi kurang salah satunya disebabkan karena kualitas makanan sebagian besar masyarakat masih belum bergizi seimbang (Hermina \& Prihatini, 2011).

Menurut Amirian, et al. (2008), buruh tani adalah bagian dari petani yang merupakan orang pertama yang turut berperan dalam penyediaan pangan masyarakat, tetapi kondisi ketahanan pangan buruh tani masih belum baik, lebih dari $80 \%$ mengalami rawan pangan. Oleh karena itu, buruh tani menjadi kelompok yang sangat rentan mengalami rawan pangan (Prihatin, et al., 2012).

Kabupaten Bojonegoro adalah salah satu Kabupaten di Jawa Timur yang mayoritas 1,3 juta penduduknya bermata pencaharian sebagai petani dan geografis Kabupaten Bojonegoro merupakan daerah dataran rendah sekaligus setiap tahunnya mengalami bencana banjir (BPS Kabupaten Bojonegoro, 2013). Terdapat 9 dari 15 Kecamatan yang dinilai kurang baik kondisi ketahanan pangannya, salah satu dari 9 kecamatan tersebut adalah Kecamatan Dander (Supardi, et al., 2012). Sebanyak 42,8\% penduduk di Kecamatan Dander adalah petani dan tidak sedikit penduduk yang tidak memiliki lahan sawah yang bekerja sebagai buruh tani (Cahyanto, 2013).

Tujuan dari penelitian ini adalah untuk menganalisis hubungan karakteristik rumah tangga dan ketersediaan pangan dengan keragaman pangan rumah tangga buruh tani di RT.17/RW.02 Kecamatan Dander Kabupaten Bojonegoro.

\section{METODE}

Penelitian ini merupakan penelitian observasional analitik dengan rancang bangun cross sectional. Populasi dalam penelitian ini adalah seluruh rumah tangga buruh tani di RT.17/ RW.02 Kecamatan Dander Kabupaten Bojonegoro. Sejumlah 35 rumah tangga buruh tani terpilih secara acak sebagai sampel penelitian yang dipilih menggunakan teknik simple random sampling.

Pengumpulan data dalam penelitian ini dilakukan dengan wawancara menggunakan kuesioner terstruktur terkait ketersediaan pangan dan kuesioner HDDS untuk menilai keanekaragaman konsumsi pangan.
Penilaian ketersediaan pangan rumah tangga berdasarkan kuesioner ketersediaan pangan yang terdiri dari beberapa jenis kelompok pangan (pangan sumber hewani, pangan sumber nabati, buah, susu/produk susu, dan sayuran) yang tersedia atau tidak tersedia. Ketersediaan pangan rumah tangga dikategorikan menjadi 2 yang dibandingkan dengan konsumsi normatif per individu (300 gram per hari), yaitu kurang apabila ketersediaan pangan $<300$ gram/hari dan cukup apabila ketersediaan pangan $\geq 300$ gram/hari (Santi, 2015).

Pendapatan dan pengeluaran juga diukur menggunakan kuesioner. Penilaian pendapatan rumah tangga terdiri dari jumlah anggota rumah tangga yang memiliki pendapatan, jumlah pendapatan kemudian ditanyakan frekuensinya, harian, mingguan atau bulanan. Total pendapatan dihitung selama satu bulan yang dihitung dari frekuensi jumlah pendapatan rumah tangga. Penilaian pengeluaran rumah tangga dikelompokkan menjadi dua yaitu pengeluaran pangan dan non pangan, diukur dahulu jumlah pengeluaran dan frekuensi pengeluaran kemudian di total menjadi pengeluaran dalam satu bulan.

Proporsi pengeluaran pangan dihitung dengan cara persentase pengeluaran pangan dibanding dengan total pengeluaran. Proporsi pengeluaran pangan diklasifikasikan menjadi 2 , yaitu $<60 \%$ dan $\geq 60 \%$ (Yudaningrum, 2011).

Kondisi keragaman pangan rumah tangga diukur dengan menggunakan kuesioner HDDS. Skor HDDS dihitung dengan cara menuliskan angka 1 pada jenis/kelompok makanan dikonsumsi dan 0 jika tidak dikonsumsi. Kemudian menjumlahkan semua skor dari semua kelompok makanan. Hasil penjumlahan berkisar antara 0 hingga 12 . Skor HDDS dikelompokkan menjadi 3 kriteria yaitu rendah $(<3)$, sedang (4-5), dan tinggi $(>6)$. Selanjutnya, dihitung rata-rata HDDS bagi rumah tangga (Dorp, 2013).

Analisis statistik yang digunakan untuk mengetahui hubungan ketersediaan pangan dengan keragaman pangan rumah tangga buruh tani adalah uji Chi-Square dengan $\alpha=0,05$. Penelitian ini telah lolos Kaji Etik oleh Komisi Etik Penelitian Kesehatan Fakultas Kesehatan Masyarakat Universitas Airlangga No. 545-KEPK. 


\section{HASIL DAN PEMBAHASAN}

Dari hasil distribusi karakteristik keluarga buruh tani yaitu mayoritas jumlah anggota rumah tangga buruh tani berjumlah $\leq 4$ orang $(68,6 \%)$. Pendapatan rumah tangga merupakan seluruh total pendapatan dari setiap anggota rumah tangga yang berpenghasilan, baik harian, mingguan, ataupun bulanan. Pendapatan rumah tangga buruh tani sebanyak $42,9 \%$ tergolong pada golongan 4 yaitu lebih dari Rp 1.100.000,00. Pengeluaran rumah tangga merupakan total pengeluaran rumah tangga untuk pangan dan non pangan. Sebanyak $40 \%$ rumah tangga buruh tani tergolong dalam golongan 4 yaitu lebih dari Rp 1.381.000,00 dan lebih dari separuh $(65,7 \%)$ rumah tangga memiliki proporsi pengeluaran pangan lebih dari 60\% (Tabel 1).

Ketersediaan pangan rumah tangga dapat dilihat dari ketersediaan stok beras di rumah per hari dalam satu minggu terakhir dan dibagi dengan unit ekuivalensi dewasa seluruh anggota rumah tangga, hasilnya dibandingkan dengan konsumsi normatif per individu yaitu 300 gram (Santi, 2015). Ketersediaan pangan rumah tangga yang dikelompokkan menjadi 2 kategori yaitu kurang apabila ketersediaan pangan $<300$ gram/hari dan cukup apabila ketersediaan pangan $\geq 300$ gram/ hari. Mayoritas buruh tani memiliki ketersediaan pangan yang kurang $(62,9 \%)$ (Tabel 1). Dalam penilaian ketersediaan pangan rumah tangga, terdapat beberapa kelompok pangan yang tersedia dan tidak tersedia di wilayah tersebut.

Menurut Hardinsyah (2007), ketersediaan pangan merupakan faktor determinan dari keragaman pangan. Dalam penelitian Hardinsyah, ketersediaan pangan di setiap wilayah berbeda karena para petani memproduksi beragam pangan sesuai dengan kondisi alam dan berbagai faktor ekologi seperti tanah, iklim, musim, dan sumber daya biologis. Pada hasil penelitian, wilayah tersebut merupakan daerah dataran rendah dan memiliki ancaman eksternal yaitu bencana banjir.

Rumah tangga dengan jumlah anggota keluarga yang terdiri dari $\leq 4$ orang sebesar $50 \%$ memiliki kondisi keragaman pangan dengan kategori sedang, sedangkan rumah tangga dengan jumlah anggota keluarga $>4$ orang sebesar $45,5 \%$ memiliki keragaman pangan yang tinggi. Menurut Hardinsyah (2007), faktor yang diduga sebagai determinan keragaman konsumsi pangan di Indonesia salah satunya adalah jumlah anggota rumah tangga. Anggota rumah tangga yang bervariasi akan turut mencerminkan variasi dalam ketersediaan pangan untuk konsumsi di rumah tangga.

Hasil penelitian ini berbeda dengan hasil review yang dilakukan Hardinsyah (2007) namun sejalan dengan penelitian Amine, et al. (2016) yang menyatakan tidak ada hubungan yang signifikan antara ukuran rumah tangga dengan keragaman pangan pada masyarakat pedesaan.

Terdapat model analisis yang umum pada determinan konsumsi pangan yaitu menggunakan ukuran rumah tangga, pendapatan atau pengeluaran dan harga. Rumah tangga berukuran besar akan mengakibatkan jenis pangan yang dikonsumsi kurang beragam dan memiliki kualitas gizi yang lebih rendah jika dibandingkan dengan keluarga yang berukuran lebih kecil (Hardinsyah, 2007). Namun, penelitian ini menunjukkan keluarga yang berukuran besar justru memiliki keragaman pangan yang tinggi dikarenakan tingkat pendapatan rumah tangga buruh tani tergolong cukup tinggi sehingga dapat memenuhi keragaman konsumsi pangan untuk keluarga.

Pendapatan rumah tangga buruh tani pada kategori golongan 1, golongan 2, dan golongan 3 sebagian besar memiliki keragaman pangan tingkat sedang. Sedangkan, pada golongan 4 sebagian besar (53,3\%) memiliki keragaman pangan tinggi. Menurut Ariani, et al. (2007), pendapatan rumah tangga yang tergolong kecil dapat mempengaruhi pola distribusi pendapatan termasuk pola konsumsi pangan karena seseorang akan lebih mengutamakan pemenuhan kebutuhan makan dan sebagian besar pendapatan hanya cukup untuk dibelanjakan untuk pangan.

Pendapatan keluarga juga berpengaruh terhadap pola konsumsi pangan. Pola konsumsi pangan seseorang akan lebih beragam seiring dengan peningkatan pendapatan yang memenuhi kuantitas dan kualitas pangan sehingga konsumsi pangan yang bernilai gizi tinggi juga akan mengalami peningkatan (Yudaningrum, 2011).

Menurut Hardinsyah (2007), hubungan antara pendapatan dengan keragaman pangan berasal dari bukti empiris yaitu terdapat perbedaan pola 
Tabel 1. Distribusi Frekuensi Karakteristik Keluarga, Ketersediaan Pangan dan Keragaman Pangan Rumah Tangga Buruh Tani

\begin{tabular}{|c|c|c|}
\hline Karakteristik Keluarga & n & $\%$ \\
\hline \multicolumn{3}{|l|}{ Jumlah Anggota Keluarga } \\
\hline$\leq 4$ orang & 24 & 68,6 \\
\hline$>4$ orang & 11 & 31,4 \\
\hline \multicolumn{3}{|l|}{ Pendapatan Keluarga } \\
\hline Golongan $1(<\operatorname{Rp} 800.000,00)$ & 5 & 14,3 \\
\hline Golongan $2(\operatorname{Rp} 800.000,00-\operatorname{Rp} 900.000,00)$ & 12 & 34,3 \\
\hline Golongan 3 (Rp 900.001,00 - Rp 1.100.000,00) & 3 & 8,6 \\
\hline Golongan 4 (>Rp 1.100.000,00) & 15 & 42,9 \\
\hline \multicolumn{3}{|l|}{ Pengeluaran Keluarga } \\
\hline Golongan $1(<\operatorname{Rp} 1.025 .000,00)$ & 5 & 14,3 \\
\hline Golongan $2(\operatorname{Rp} 1.025 .000,00$ - Rp 1.272.000,00) & 9 & 25,7 \\
\hline Golongan 3 (Rp 1.272.001,00 - Rp 1.381.000,00) & 7 & 20,0 \\
\hline Golongan 4 (>Rp 1.381.000,00) & 14 & 40,0 \\
\hline \multicolumn{3}{|l|}{ Proporsi Pengeluaran Pangan } \\
\hline$<60 \%$ & 12 & 34,3 \\
\hline$\geq 60 \%$ & 23 & 65,7 \\
\hline \multicolumn{3}{|l|}{ Ketersediaan Pangan Rumah Tangga } \\
\hline Kurang & 22 & 62,9 \\
\hline Cukup & 13 & 37,1 \\
\hline \multicolumn{3}{|l|}{ Jenis Pangan yang Tidak Tersedia } \\
\hline Protein hewani & 1 & 3,3 \\
\hline Protein nabati & 2 & 6,7 \\
\hline Buah & 1 & 3,3 \\
\hline Susu / produk susu & 8 & 26,7 \\
\hline Protein nabati dan susu & 3 & 10,0 \\
\hline Buah dan susu & 12 & 40,0 \\
\hline Sayuran, buah, dan susu & 3 & 10,0 \\
\hline \multicolumn{3}{|l|}{ Keragaman Pangan } \\
\hline Rendah & 4 & 11,4 \\
\hline Sedang & 16 & 45,7 \\
\hline Tinggi & 15 & 42,9 \\
\hline
\end{tabular}

konsumsi pangan kelompok menengah ke atas dan menengah ke bawah. Pada kelompok menengah ke bawah, pola konsumsi lebih sederhana dimana mereka lebih mengutamakan mengonsumsi sumber kalori yang murah (bahan pangan pokok), sedangkan pada kelompok menengah ke atas, pola konsumsi pangannya lebih beragam dengan lebih banyak mengonsumsi sumber protein dan vitamin.

Dari hasil penelitian, tidak terdapat hubungan pendapatan dengan keragaman pangan rumah tangga buruh tani. Hal ini dapat disebabkan pendapatan rumah tangga buruh tani masih dibawah UMK (Upah Minimum Kabupaten)
Kabupaten Bojonegoro. Pendapatan buruh pada golongan tertinggi yaitu $>$ Rp 1.100.000,00 sementara itu nilai UMK Kab. Bojonegoro adalah Rp 1.462.000,00. Dari hasil survei wawancara dengan istri, suami (kepala rumah tangga) selain bekerja sebagai buruh tani, juga memiliki pekerjaan sampingan yaitu sebagai kuli bangunan. Cara adaptasi rumah tangga yang dapat dilakukan untuk menangani masalah pangan yaitu mengubah pola kerja dengan cara berburuh di luar sektor pertanian (Hanani, 2012).

Rumah tangga yang berada pada golongan pengeluaran 1 dan 2 sebagian besar memiliki 
Tabel 2. Kondisi Keragaman Pangan Rumah Tangga Buruh Tani menurut Karakteristik Keluarga Dan Ketersediaan Pangan Rumah Tangga Buruh Tani

\begin{tabular}{|c|c|c|c|c|c|c|c|c|c|}
\hline \multirow{3}{*}{ Karakteristik } & \multicolumn{6}{|c|}{ Keragaman Pangan } & \multicolumn{2}{|c|}{ Total } & \multirow{3}{*}{ p value } \\
\hline & \multicolumn{2}{|c|}{ Rendah } & \multicolumn{2}{|c|}{ Sedang } & \multicolumn{2}{|c|}{ Tinggi } & \multirow{2}{*}{$\mathbf{n}$} & \multirow{2}{*}{$\%$} & \\
\hline & $\mathbf{n}$ & $\%$ & n & $\%$ & $\mathbf{n}$ & $\%$ & & & \\
\hline \multicolumn{10}{|c|}{ Jumlah Anggota Rumah Tangga } \\
\hline$\leq 4$ orang & 2 & 8,3 & 12 & 50,0 & 10 & 41,7 & 24 & 100,0 & \multirow{2}{*}{0,615} \\
\hline$>4$ orang & 1 & 18,2 & 4 & 36,4 & 5 & 45,5 & 11 & 100,0 & \\
\hline \multicolumn{10}{|c|}{ Pendapatan Rumah Tangga } \\
\hline Golongan 1 & 2 & 22,2 & 5 & 55,6 & 2 & 22,2 & 9 & 100,0 & \multirow{4}{*}{0,103} \\
\hline Golongan 2 & 1 & 7,7 & 8 & 61,5 & 4 & 30,8 & 13 & 100,0 & \\
\hline Golongan 3 & 1 & 33,3 & 1 & 33,3 & 1 & 33,3 & 3 & 100,0 & \\
\hline Golongan 4 & 0 & 0,0 & 2 & 20,0 & 8 & 80,0 & 10 & 100,0 & \\
\hline \multicolumn{10}{|c|}{ Pengeluaran Rumah Tangga } \\
\hline Golongan 1 & 2 & 25,0 & 4 & 50,0 & 2 & 25,0 & 8 & 100,0 & \multirow{4}{*}{0,412} \\
\hline Golongan 2 & 1 & 12,5 & 5 & 62,5 & 2 & 25,0 & 8 & 100,0 & \\
\hline Golongan 3 & 1 & 12,5 & 2 & 25,0 & 5 & 62,5 & 8 & 100,0 & \\
\hline Golongan 4 & 0 & 0,0 & 5 & 45,5 & 6 & 54,5 & 11 & 100,0 & \\
\hline \multicolumn{10}{|c|}{ Ketersediaan Pangan Rumah Tangga } \\
\hline Kurang & 3 & 13,6 & 14 & 63,6 & 5 & 22,7 & 22 & 100,0 & \multirow{2}{*}{0,007} \\
\hline Cukup & 1 & 7,7 & 2 & 15,4 & 10 & 76,9 & 13 & 100,0 & \\
\hline
\end{tabular}

kondisi keragaman pangan yang sedang, sedangkan pada golongan 3 dan golongan 4 sebagian besar memiliki keragaman pangan tinggi. Pola daya beli pangan menjadi faktor penting sebagai determinan dalam keragaman pangan. Daya beli pangan merupakan kemampuan ekonomi rumah tangga untuk memperoleh bahan pangan yang ditentukan oleh besarnya alokasi pendapatan untuk pangan, harga bahan pangan yang dikonsumsi, dan jumlah anggota keluarga (Hardinsyah, 2007).

Hasil studi menunjukkan bahwa tidak terdapat hubungan antara pengeluaran pangan dengan keragaman pangan rumah tangga buruh tani. Hal tersebut disebabkan proporsi pengeluaran pangan rumah tangga buruh tani tergolong tinggi, dimana daya beli pangan tergantung pada besarnya pendapatan dan harga bahan pangan, dimana pada rumah tangga buruh tani sendiri pendapatannya masih di bawah UMK. Seiring berubahnya pengeluaran untuk pangan, maka akan terjadi perubahan pada jumlah dan jenis pangan yang dikonsumsi (Hardinsyah, 2007). Dari hasil penelitian, proporsi pengeluaran pangan $\geq 60 \%$ atau tergolong tinggi yaitu sebesar $65,7 \%$ (Tabel 1). Dalam penelitian yang lain menyebutkan bahwa konsumsi pangan yang tinggi menunjukkan kesejahteraan rumah tangga yang rendah karena hanya mampu memenuhi kebutuhan pangan saja (Nilasari, et al., 2012). Hal ini sejalan dengan penelitian Prasmatiwi, et al. (2012) yang menunjukkan bahwa rumah tangga yang memiliki alokasi pengeluaran pangan yang tinggi akan berakibat pada pemenuhan kecukupan energi yang kurang. Pengeluaran yang digunakan untuk pangan hanya memenuhi dari segi kuantitas pangan saja dan hanya dapat memenuhi rasa kenyang, tetapi kualitas pangan untuk memenuhi kecukupan gizi masih belum dipenuhi.

Hardinsyah (2007) mengemukakan pandangan umum mengenai hubungan antara pengeluaran pangan dan keragaman konsumsi pangan bahwa perubahan pengeluaran untuk pangan pada rumah tangga akan mengubah jumlah dan jenis pangan yang dikonsumsinya. Namun, pengeluaran pangan tidak hanya dipengaruhi oleh pendapatan saja melainkan dipengaruhi juga oleh tingkat pengetahuan gizi dan ukuran anggota rumah tangga.

Hasil penelitian menunjukkan bahwa terdapat hubungan antara ketersediaan pangan dengan 
keragaman pangan rumah tangga buruh tani $(\mathrm{p}<0,05)$ (Tabel 2). Pentingnya kesadaran untuk mengonsumsi jenis pangan yang beragam akan memberikan dampak yang positif bagi kesehatan tubuh, bagi ibu hamil berat kelahirannya akan cukup, bagi anak-anak akan memiliki status gizi yang baik, dan akan terjadi status peningkatan hemoglobin yang dapat menurunkan kejadian anemia (Dorp, 2013). Ketersediaan pangan yang cukup akan memenuhi kecukupan energi seseorang yang didapatkan dari pangan yang mengandung karbohidrat, protein dan lemak. Apabila ketersediaan tidak lengkap akan berpengaruh terhadap status gizi seseorang (Pahlevi, 2012).

Dari hasil penelitian ini, rumah tangga dengan ketersediaan pangan yang kurang, sebagian besar memiliki keragaman pangan yang sedang $(63,6 \%)$ dan rumah tangga dengan ketersediaan pangan yang cukup sebagian besar memiliki keragaman pangan yang tinggi $(76,9 \%)$ (Tabel 2 ).

Keragaman konsumsi pangan dapat dipengaruhi oleh ketersediaan pangan yang ditentukan dari nilai-nilai kebiasaan/adat (tradisi dan kepercayaan) yang berhubungan dengan pangan, pengetahuan gizi dan kualitas pangan. Menggantikan beberapa jenis pangan tertentu dengan pangan lain yang memiliki kandungan gizi serupa membawa konsekuensi pada ketersediaan pangan yang mungkin berhubungan dengan keragaman pangan seperti yang telah diperhitungkan dari keragaman konsumsi pangan sejenis tetapi tidak dengan keragaman pangan seperti yang telah diperhitungkan dari sebagian besar kelompok pangan. Jika jenis pangan di seluruh wilayah yang tersedia sama, maka akan sulit untuk memasukkan jenis pangan yang tersedia sebagai salah satu determinan keragaman konsumsi pangan (Hardinsyah, 2007). Keragaman pangan setiap wilayah berbeda-beda dan dipengaruhi oleh faktor luar seperti iklim, kondisi tanah dan keadaan biologis wilayah, yang nantinya berpengaruh terhadap ketersediaan pangan di wilayah tersebut.

Berdasarkan penelitian sebelumnya, keragaman pangan pada petani memiliki lebih dari 65 jenis pangan yang dikumpulkan di rumah dan siap untuk dimakan. Dari jenis pangan tersebut, lebih dari $70 \%$ makanan yang dikonsumsi keluarga diperoleh dari membeli di pasar, dan setiap harinya mengonsumsi paling sedikit 5 jenis pangan (Bellon et al., 2016). Bellon, et al. (2016) meneliti tentang keterkaitan antara pertanian, pasar dan keragaman pangan. Hasil dari penelitian tersebut terdapat keterkaitan yang positif antara pertanian, pasar dan keragaman pangan.

\section{KESIMPULAN DAN SARAN}

Hasil penelitian menunjukkan bahwa tidak terdapat hubungan antara karakteristik keluarga, tetapi terdapat hubungan ketersediaan pangan dengan keragaman pangan rumah tangga buruh tani di RT 17/RW 02 Kecamatan Dander Kabupaten Bojonegoro. Penelitian ini merekomendasikan kepada Dinas Pertanian Kabupaten Bojonegoro untuk lebih meningkatkan ketersediaan pangan sehingga keragaman pangan dapat meningkat.

\section{DAFTAR PUSTAKA}

Amine, B.M \& Fatima, B. (2016). Determinants of on-farm diversification among rural households: Empirical evidence from Northern Algeria. International Journal of Food and Agricultural Economics, 4 (2), 87-99. Diakses dari http:// www.foodandagriculturejournal.com/vol4.no2. pp87.pdf.

Amirian., Yayuk, F.B., \& Lilik, K. (2008). Ketahanan pangan rumah tangga petani sawah di wilayah enclave Taman Nasional Bukit Barisan Selatan. Jurnal Gizi dan Pangan, 3(3), 132-138.

Ariani, M., Ariningsih, I.K., \& Maulana, M. (2007). Kinerja dan prospek pemberdayaan rumah tangga rawan pangan dalam era desentralisasi. Kerjasama Penelitian Biro Perencanaan, Departemen Pertanian, dan UNESCAPPASCA, Bogor.

Badan Ketahanan Pangan. (2009). Peraturan presiden nomor 22 tahun 2009 tentang kebijakan percepatan penganekaragaman konsumsi pangan berbasis sumber daya lokal. Jakarta: Badan Ketahanan Pangan. Diakses dari bkp.pertanian.go.id/tinymcpuk/gambar/file/ Perpres_22_Tahun_2009.pdf.

Badan Pusat Statistik (BPS) Kabupaten Bojonegoro. (2013). Profil Kelurahan Dander, Kabupaten Bojonegoro. Bojonegoro: BPS. 
Bellon, M.R., Gervais, D.N.B., \& Francesco, C. (2016). Onfarm diversity and market participation are positively associated with dietary of rural mothers in Southern Benin, West Africa. PLOS ONE Journal, 1-20. DOI:10.1371/ journal.pone.0162535 71. Diakses dari http:// journals.plos.org/plosone/article?id=10.1371/ journal.pone.0162535.

Cahyanto, A.D. (2013). Kajian kondisi sosial, ekonomi, lingkungan terbangun dan program pemerintah terhadap banjir Bengawan Solo Di Desa Ngablak Kecamatan Dander Kabupaten Bojonegoro. Jurnal Pendidikan Geografi, 3(2), 360-368. Diakses dari http://jurnalmahasiswa. unesa.ac.id/index.php/swara-bhumi/article/ view/6922/9464.

Departemen Pertanian. (2004). Kinerja Sektor Pertanian Tahun 2000-2003. Jakarta: Departemen Pertanian.

Dorp, V.M. (2013). Gizi rumah tangga dan pengolahan makanan. Medan: SCPP. Diakses dari http://www.swisscontact.org/fileadmin/ user_upload/COUNTRIES/Indonesia/ Documents/Publications/Manual_04_-_ Household_Nutrition_and_Food_Preparation. pdf.

Hanani, N. (2012). Strategi pencapaian ketahanan pangan keluarga. E-Journal Ekonomi Pertanian, 1(1), 1-10. Diakses dari nuhfil.lecture.ub.ac.id/ files/2012/12/ketahanan-pangan-keluarga.pdf.

Hardinsyah. (2007). Review faktor determinan keragaman konsumsi pangan. Jurnal Gizi dan Pangan, 2(2), 55-74. Diakses dari http:// repository.ipb.ac.id/handle/123456789/52502.

Hermina dan Prihatini, S. (2011). Gambaran keragaman makanan dan sumbangannya terhadap konsumsi energi protein pada anak balita pendek (stunting) di Indonesia. Jurnal Bul.Penelit. Kesehat (Badan Litbangkes Kemenkes RI), 39(2), 62-73. Diakses dari ejournal.litbang.depkes.go.id/index.php/BPK/ article/view/70.

Nilasari, A., Harisudin, M., \& Widiyanto. (2012). Analisis hubungan antara pendapatan dengan proporsi pengeluaran pangan dan kecukupan gizi rumah tangga petani di Kabupaten Cilacap. Diakses dari https://digilib.uns. ac.id/dokumen/download/29904/NjI5OTE=/ Analisis-Hubungan-Antara-Pendapatan-
Dengan-Proporsi-Pengeluaran-Pangan-DanKecukupan-Gizi-Rumah-Tangga-Petani-DiKabupaten-Cilacap-abstrak.pdf.

Pahlevi, A.E. (2012). Determinan status gizi pada siswa sekolah dasar. Jurnal Kesehatan Masyarakat (KEMAS), 7(2), 122-126. Diakses dari https://journal.unnes.ac.id/artikel_nju/ kemas/2807.

Prasmatiwi, F.E., Indah, L, \& Novi, R. (2012). Pengaruh intensifikasi pertanian terhadap ketahanan pangan rumah tangga petani padi di Lampung Tengah. PROSIDING SNSMAIP III-2012. Diakses dari http://jurnal.fmipa.unila. ac.id/index.php/snsmap/article.

Prihatin, S.D., Hariadi, S.S., \& Mudiyono. (2012). Ancaman ketahanan pangan rumah tangga petani. Jurnal Ilmiah CIVIS (Civil for Society), 2 (2). Diakses dari https://www.google.co.id/s earch?ei=m5UOWpeeMsGBvwS7x66QCw\& $\mathrm{q}=$ Ancaman + ketahanan + pangan + rumah + tan gga + petani.\&oq $=$ Ancaman + ketahanan + pang an + rumah + tangga + petani.\&gs_l=psy-ab.3..3 $3 \mathrm{i} 22 \mathrm{i} 29 \mathrm{i} 30 \mathrm{k} 112.1814729 .1814729 .0 .1815055$ .1.1.0.0.0.0.268.268.2-1.1.0...0...1.1.64.psyab..0.1.264...0.cA42pe4z9EE.

Santi. (2015). Faktor-faktor yang berhubungan dengan ketahanan pangan rumah tangga penerima raskin (studi di Kelurahan Tompokersan, Kabupaten Lumajang) (Skripsi tidak diterbitkan). Universitas Airlangga, Surabaya.

Santi. (2015). Hubungan ketersediaan pangan dan keteraturan penerimaan raskin dengan status ketahanan pangan rumah tangga penerima raskin. Jurnal Media Gizi Indonesia, 10(2),97103. Diakses dari: e-journal.unair.ac.id/index. php/MGI/article/view/3312.

Supardi, S., Erlyna, W.R., \& Aulia, Q. (2012). Pemetaan kondisi kerawanan pangan di tingkat wilayah di Kabupaten Bojonegoro. Jurnal Ilmu-Ilmu Pertanian, 16(2), 84-90. Diakses dari https://eprints.uns.ac.id/13690/1/Publikasi Jurnal_(11).pdf.

Yudaningrum, A. (2011). Analisis hubungan proporsi pengeluaran dan konsumsi pangan rumah tangga petani di Kabupaten Kulon Progo (Skripsi, Universitas Sebelas Maret. Surakarta). Diakses dari http://eprints.uns.ac.id.5208/. 